\title{
Gametogenesis and reproductive cycle of Melanorivulus aff. punctatus (Boulenger, 1895) (Cyprinodontiformes, Rivulidae) in Chapada dos Guimarães, Mato Grosso, Brazil
}

\author{
Mônica Cassel ${ }^{1}$, Mahmoud Mehanna $^{2}$, Lúcia Mateus $^{1}$ and Adelina Ferreira ${ }^{1}$
}

The comprehension of the reproductive cycle allows to understand which are the morphological changes that develop in the gonad during this interval. Thus, many studies have been undertaken in order to describe and classify the stages of gonadal development and reproductive status of Neotropical fishes. For this purpose, specimens of Melanorivulus aff. punctatus were collected in a permanent dam in Chapada dos Guimarães, Mato Grosso, Brazil. The gonads were prepared for analysis by light microscopy. The oogenesis and spermatogenesis have been described, characterizing the stages of gonadal development, together with assessments of the gonadosomatic ratio, germ cell count and verification of variation of mature oocytes in females. Throughout the year the male gonads presented themselves as capable of reproducing, characterized by the presence of undifferentiated and differentiated spermatogonia, spermatocytes organized into cysts, spermatids in cysts whose wall was thicker and the spermatozoa was free in the lumen and the duct. This can indicate a continuous reproductive cycle with split spermiation. The females had gonads in the development stage from May to September with undifferentiated and differentiated oogonias and early oocytes always facing the lumen, abundant pre-vitellogenic and vitellogenic oocytes and some atresias. In the phase capable of spawning, observed from October to March, the mature oocytes are abundant, there are many post-ovulatory complexes and some atresia in advanced stage. The regression, observed in some individuals from February to April, is characterized by ovaries with many atresias and post-ovulatory complexes. The same results were found in the quantitative assessments. Therefore, it may be characterized as discontinuous cycle with split spawning. Thus, the reproductive cycle of this species can be characterized as continuous for males and discontinuous for females, which have a most intense phase of reproduction from October to March. However, both have fractional release of gametes.

A compreensão do ciclo reprodutivo possibilita entender quais são as mudanças morfológicas que se desenvolvem na gônada neste período. Assim, muitos estudos têm sido realizados no intuito de descrever e classificar as fases de desenvolvimento gonadal e dos estados reprodutivos dos peixes da região Neotropical. Com esse objetivo foram coletados espécimes de Melanorivulus aff. punctatus em um represamento permanente em Chapada dos Guimarães, Mato Grosso, Brasil. As gônadas foram preparadas para análise à microscopia de luz. A ovogênese e a espermatogênese foram descritas e caracterizados os estágios de desenvolvimento gonadal, juntamente com as avaliações de razão gonadossomática, contagem de células germinativas e verificação de variação de ovócitos maduros em fêmeas. Durante todo o ano as gônadas masculinas apresentaram-se como aptas a reprodução, caracterizadas pela presença de espermatogônias indiferenciadas e diferenciadas, espermatócitos organizados em cistos, espermátides em cistos com parede mais espessa e espermatozoides livres no lúmen e no ducto. Isso pode indicar um ciclo reprodutivo contínuo com espermiação parcelada. As fêmeas apresentaram gônadas em estágio de desenvolvimento de maio a setembro, com ovogônias indiferenciadas e diferenciadas e ovócitos iniciais sempre voltados para o lúmen, ovócitos pré-vitelogênicos e vitelogênicos abundantes e algumas atresias. Na fase de apto a desova, observada de outubro a março, os ovócitos maduros são abundantes, há muitos complexos pós ovulatórios e algumas atresias em estágio avançado. A fase de regressão, constatada em alguns indivíduos de fevereiro a abril, é caracterizada por ovários com muitas atresias e complexos pós-ovulatórios. Os mesmos resultados foram encontrados nas avaliações quantitativas realizadas. Logo, pode-se caracterizar o ciclo como descontínuo com desova parcelada. Assim, o ciclo reprodutivo desta espécie pode ser caracterizado como contínuo para machos e descontínuo para fêmeas, que apresentam uma fase mais intensa de reprodução de outubro a março. Porém, ambos possuem liberação de gametas parcelada.

Key words: Gonadossomatic ratio, Histology, Oogenesis, Spermatogenesis.

${ }^{1}$ Universidade Federal de Mato Grosso, Programa de Pós-graduação em Ecologia e Conservação da Biodiversidade, Instituto de Biociências. Av. Fernando Corrêa da Costa, nº 2367, Bairro Boa Esperança, 78060-900 Cuiabá, MT, Brazil. monicassel@hotmail.com (MC); adelina@ufmt.br(AF)

${ }^{2}$ Universidade Estadual Paulista "Júlio de Mesquita Filho", UNESP, Campus de Botucatu, Instituto de Biociências, Departamento de Morfologia, Laboratório de Biologia e Genética de Peixes, Distrito de Rubião Júnior, S/N, 18618-970 Botucatu, SP, Brazil. 


\section{Introduction}

The comprehension of the reproductive cycle allows to understand which are the morphological changes that develop in the gonad during this interval. These changes, when compared with anthropogenic or environmental factors that vary at the same time, enable us to understand what factors may determine the stages of gonadal development, especially in relation to the processes of proliferation and differentiation in the formation of gametes (Munro, 1990a, 1990b; Wootton, 1990; Vazzoler, 1996; Suzuki et al., 2004).

The gonadal development can be analyzed macroscopically and the changes in the shape, size, color, and texture of gonads have been used as parameters for classification of maturation in many studies of ecology and reproductive dynamics (Wallace \& Sellman, 1981; Vazzoler, 1996). Regarding the microscopic aspects of the gonad, it has been found that gametogenesis is similar for all teleosts. Spermatogenesis proceeds through universal stages of development, including spermatogonia, spermatocytes, spermatids, and spermatozoa. The oogenesis, in turn, usually shows the following progression: oogonia, primary growth oocytes, pre-vitellogenic oocytes wherein there is an increase in size and often have cortical alveolar vesicles, an extensive vitellogenic phase, oocyte maturation and ovulation (Lowerre-Barbieri et al., 2011).

Many studies have been undertaken in order to describe and classify the stages of gonadal development and reproductive status of Neotropical fishes. One of the classical literature sources that have been used is Vazzoler (1996), however other proposals for description have been made by Grier \& Taylor (1998), Grier (2002), Lo Nostro et al. (2003), detailing the continuity and discontinuity of the germinal epithelium and the cell types present in the gonads. Finally, Brown-Peterson et al. (2011) developed a simpler terminology to facilitate the communication and comparison of studies on the reproductive biology of fishes. Furthermore, they have been working towards improving its proposal that includes the concepts of the germinal epithelium broadcast by Grier (2000).

The greatest difficulty in using these proposals is that they were developed primarily for marine species and Perciformes. Recent studies have exposed significant differences in the pattern of oocyte development among species of marine and fresh water, or between the basal taxa as compared with those more derivatives (Le Menn et al., 2007; Grier et al., 2009). In order to make the nomenclature more comprehensive, the stages of oocyte development were simplified by Quagio-Grassiotto et al. (2011) and the development stages of atresia, which are characterized as involution processes, following according to Miranda et al. (1999). However, the new terminology does not invalidate the proposal of Brown-Peterson et al. (2011).

Another method widely used in reproductive analyzes to check the reproductive period is the expression of gonadal weight as a percentage of body weight (DeVlamming et al., 1982). The gonadosomatic ratio (GSR) provides a simple measure of the degree of gonadal development, an alternative to the most accurate but more laborious methods, such as gonad histology or measurements of oocyte diameter (West, 1990). The GSR tends to vary along the reproductive cycle in direct proportion to the change in weight of the gonads. For females, the weight variation of the ovary is influenced largely by the size of the eggs and the number of mature oocytes. Thus, the ovary increases with the development of the oocytes reaching the peak with a large number of mature oocytes and decreasing in size when releases them (Jons \& Miranda, 1997). As ovarian maturation and fecundity of the fish are linked to the energy reserve of the individual, it is necessary to consider that the presence or absence of these reserves can cause variations in the egg production (e.g., Coward \& Bromage, 1999; Marshall et al., 1999 ) with the probability of impacts on the allometry of the ovary (Somarakis et al., 2004).

Rivulidae is composed by the subfamilies Kryptolebiatinae, Cynolebiatinae, and Rivulinae (Costa 2003, 2004a, 2004b, 2011) and 33 genera, which precedes the phylogeny proposed by Costa (2011). In the subfamily Rivulinae, the genus Rivulus, which was one of the most specious, was redimensioned by Costa (2011) in other 5 genera, for the Brazilian continental waters, which previously comprised the genus Rivulus was allocated as the new genus Melanorivulus, preceded earlier by Costa (2006) as subgenus.

The Melanorivulus punctatus species complex is distributed in the Paraguay River, upper Paraná River and down the Amazon River drainage in Brazil, Bolivia, Paraguay, and Argentina (Costa, 2011). The maximum size (standard length) recorded in adult males was $35.2 \mathrm{~mm}$ and $30.9 \mathrm{~mm}$ in females. The preferred habitats of M. punctatus are characterized by as shallow (usually less than $30 \mathrm{~cm}$ ), with slow or absent currents and muddy or sandy substrate. Individuals normally inhabit the area near the surface of the water between marsh and aquatic plants or submerged bushes and grass (Schindler \& Etzel, 2008).

Most work in relation to the Rivulidae family mainly emphasizes the morphological analyses relative to phylogeny (Parenti, 1981; Costa, 1989, 1990, 2005) molecular (Murphy \& Collier, 1997; Costa, 2011) and reproduction (Arenzon et al., 1999; Shibatta, 2005; Arezo et al., 2007; Gonçalves et al., 2011). However, only one study used histological analyzes as a tool for the understanding of its reproductive cycle (Arezo et al., 2007). In this context, the objective of this paper is to describe spermatogenesis and oogenesis and understand the reproductive cycle of Melanorivulus aff. punctatus in a perennial reservoir. We used the approaches proposed by Brown-Peterson et al. (2011) and Vazzoler (1996), the first one is the most recent and complete literature for description of the reproductive cycle and the second proposes the gonadosomatic ratio analysis as a complementary technique to that described 
for the cycle. Because the environment be a perennial reservoir we expect to see a reproductive cycle without interruption, with splitted spawning and gonadosomatic ratio values displaying little variation.

\section{Material and Methods}

The collections were made in a perennial reservoir in the

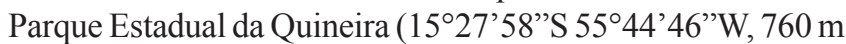
altitude) located in central urban area of Chapada dos Guimarães, Mato Grosso, Brazil. The park was created as a conservation area by state law $n^{0} 8.615 / 2006$ of December $26^{\text {th }}$ 2006 and covers an area of 261,370.62 square meters (H" 26.2 hectares). In Chapada dos Guimarães region are present streams forming the sub-basin of the Cuiabá River, such as the Manso River and its tributaries (the rivers Casca and Quilombo), which run in an area of Cerrado stricto sensu (Maitelli, 2005; Schwenk, 2005). The reservoir is formed from artificially dammed streams for the purpose of collecting water for the town of Chapada dos Guimarães. Thus, it may be considered as permanent, however its depth varies during the year in accordance with the amount of rainfall. The substrate is clayey with abundant submerged aquatic vegetation and the riparian vegetation consists of grasses, shrubs and canopy trees up to 20 meters tall.

Samples were collected with the sieve of $60 \mathrm{~cm}$ diameter and $2 \mathrm{~mm}$ mesh, monthly from April/2010 to March/2011, with one hour of sampling effort. The sampling area was limited to areas with dense vegetation rooted on the bank as the species uses these sites as refuges from predators (Schindler \& Etzel, 2008). The fishes caught were identified based on the papers of Costa $(1989,2005$, and 2011) as an undescribed species belonging to the Melanorivulus punctatus species complex, and named herein as Melanorivulus aff. punctatus.

All individuals were fixed in 2\% glutaraldehyde and 4\% paraformaldehyde in Sorensen buffer (0.1 M / pH 7.2). The separation of males and females was based on their sexual dimorphism where females have in their external morphology an eyespot at the top of the caudal peduncle. Immature individuals were considered those that the gonads were imperceptible and therefore were not examined histologically. All mature individuals were analyzed histologically.

The individuals were measured on the values of total length in $\mathrm{mm}(\mathrm{SL})$, total weight in grams (Wt) and gonads were extracted and weighed ( $\mathrm{Wg}$ - gonad weight in grams) on an analytical balance accurate to $0.001 \mathrm{~g}$. The gonads were removed and individualized in plastic eppendorf tubes containing the same fixative solution for 48 hours. After the procedure of fixation the gonads were washed with water, dehydrated in $70 \%$ alcohol for 24 hours, $95 \%$ alcohol for 4 hours, and 95\% alcohol added to plastic resin type glycol methacrylate in the ratio $1: 1$ by 8 hours. Finally, they were infiltrated in this plastic resin without catalyst for 24 hours and included in the same resin added catalyst. The blocks were cut with glass knives to $3 \mathrm{~mm}$ thick. These cuts were collected sequentially with about $30 \mathrm{~mm}$ between each other so that each blade contained 3-5 slices. Were produced 1-3 blades for individual. The blades were stained by the dye combinations of iron hematoxylin/eosin, toluidine blue-borax and PAS+Hematoxilin+Metanil Yellow (Quintero-Hunter et al., 1991). The cuts produced were used for characterization of spermatogenesis and oogenesis, and the reproductive cycle of both sexes, according to Brown-Peterson et al. (2011).

In order to verify the reproductive season for the species studied, was estimated the gonadosomatic ratio (GSR) of females, which is the percentage that the gonads represent of the total weight of the individual in accordance with the expression established by Vazzoler (1996): $\mathrm{RGS}=(\mathrm{Wg} / \mathrm{Wt}) * 100$. The comparison of $\mathrm{RGS}$ between the months was analyzed using the parametric statistical test ANOVA. Additionally, histological sections of gonads of females were used in the counting of oocytes to quantitatively determine the distribution of germ cell types present in the gonads monthly. Thereto it was draft one blade of each female collected in each month and counted the germ cells in the first three cuts. The germ cell types were described and classified as: oogonia, early oocyte, pre-vitellogenic oocyte, vitellogenic oocyte, mature oocyte, post-ovulatory processes (POCs), and atresia, as established by Quagio-Grassiotto et al. (2011). Later, it was proceeded the quantitative analysis of germ cells by calculating the proportion of cell classes, monthly, according to the stage of development and compared the total number of mature oocytes from each female per month with the test ANOVA.

After completing these steps the fishes were deposited in the Coleção de Peixes da Universidade Federal de Mato Grosso (CPUFMT) as voucher specimens (CPUFMT 1417-1428).

\section{Results}

A total of 1365 individuals were collected and analyzed. Of these, 1091 individuals, representing $79 \%$ of all individuals collected were immature. The weight and length of the males ranged from $0.990-0.008 \mathrm{~g}(0.208 \pm 0.206)$ and $43-8 \mathrm{~mm}$ $(24.33 \pm 8.95)$, respectively. As for females, the values ranged from $0.897-0.005 \mathrm{~g}(0.142 \pm 0.157)$ and $42-9 \mathrm{~mm}(21.89 \pm 6.80)$, respectively.

The male gonads showed similar appearance throughout the year, with translucent radiations from a dark center. In females with a pronounced reproductive status are observed macroscopically the mature oocytes that characterize the gonads by presenting rounded bumps on your wall. The macroscopic aspect of the male gonad was very similar to the macroscopic appearance of the female gonad in periods of reduced presence of mature oocytes.

Spermatogenesis and the male reproductive cycle. The testicles are restricted lobular type in which the germinal compartment is digitiform ending in blind bottom (Fig. 1A). The spermatogonia are confined to the distal portion of lobes 
forming cysts, with the genesis the cysts move along the lobes and in the end they open and the sperm are released (Fig. 1A). Thus, two compartments are well observed in the testis: the germinal and interstitial. The interstitial compartment contains blood vessels, myoid cells, connective tissue and the Leydig cells with steroidogenic function (Fig. 1B). The germinal compartment contains the germ cells that begin their differentiation and proliferation through the spermatogonia.

The spermatogonia divide and renew themselves so that there are spermatogonia designed to be stem cells and those intended for the genesis. Each spermatogonium is surrounded by a cytoplasmic extension of Sertoli cells that also have, among others, the support and steroidogenic functions (Fig. 1B). The spermatogonium that is a stem cell remains in contact with the basal membrane of the germinal epithelium and is large and clear with little visible nucleus. The spermatogonia intended for the genesis form cysts organized by the Sertoli cells and in each cyst the cell development is synchronous (Fig. 1C). These spermatogonia may also be called secondary then entering meiosis and give rise to primary spermatocytes (Fig. 1D). These pass through a second meiosis and give rise to secondary spermatocytes (Fig. 1D), ending the cell division and becoming spermatids (Fig. 1E). This process is already well known and there were no notable variations in light microscopy for Melanorivulus aff. punctatus. Until the morphological differentiation these spermatids remain

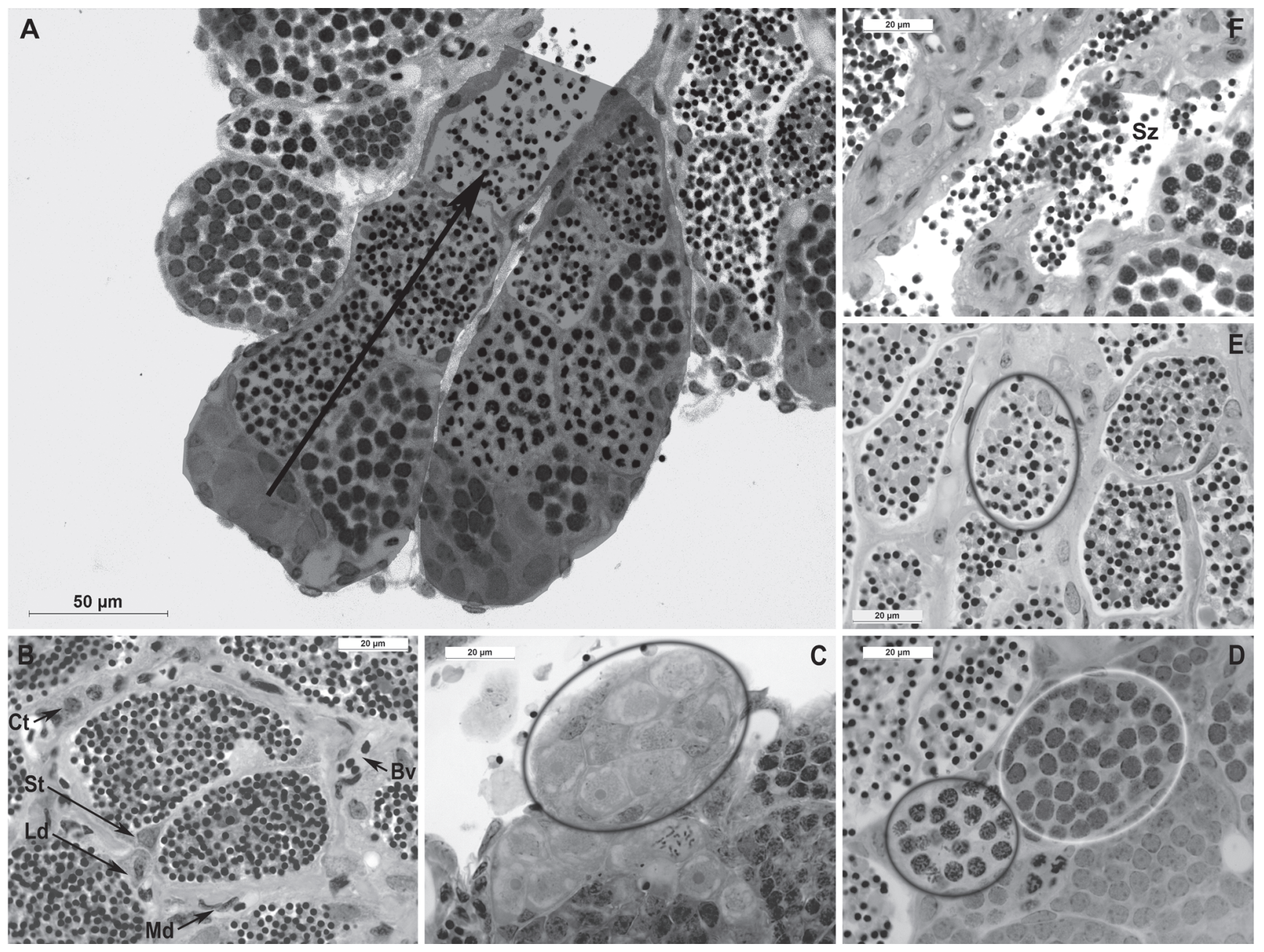

Fig. 1. In the testes, stained with toluidine blue-borax, (A) the germinal compartment is digitiform ending in blind bottom and the genesis of the germ cells follows from the distal portion of the lobes to the lumen, as indicated by lines drawn and the arrow, respectively; (B) the interstitial compartment contains blood vessels (Bv), myoid cells (Md), connective tissue $(\mathrm{Ct})$ and Leydig cells (Ld); (C) there are spermatogonia that begin the genesis and form cysts (circle) organized by the Sertoli cells (B - St); (D) this gives rise to the primary spermatocytes (white circle), and then the secondary spermatocytes (black circle); (E) so occurs the formation of the spermatids (circle); (F) and the cysts break to release the spermatozoa $(\mathrm{Sz})$. 
within the cysts which only break to release the sperm (Fig. 1F), characterizing a genesis of cystic type.

The male gonads presented themselves as able to reproduce in all months of the year. So that is always present in the gonads the spermatogonia, spermatocytes cysts arranged in the bottom of the lobes, spermatids cysts in which the wall is thicker and the sperm that is free in the lumen and duct. The germinal epithelium is always continuous under peripheral cysts and discontinuous when opening into the lumen. The remaining stages of the cycle such as regression and regeneration were not observed for male individuals. This leads us to characterize the cycle as continuous with splitted spermiation (Fig. 2).
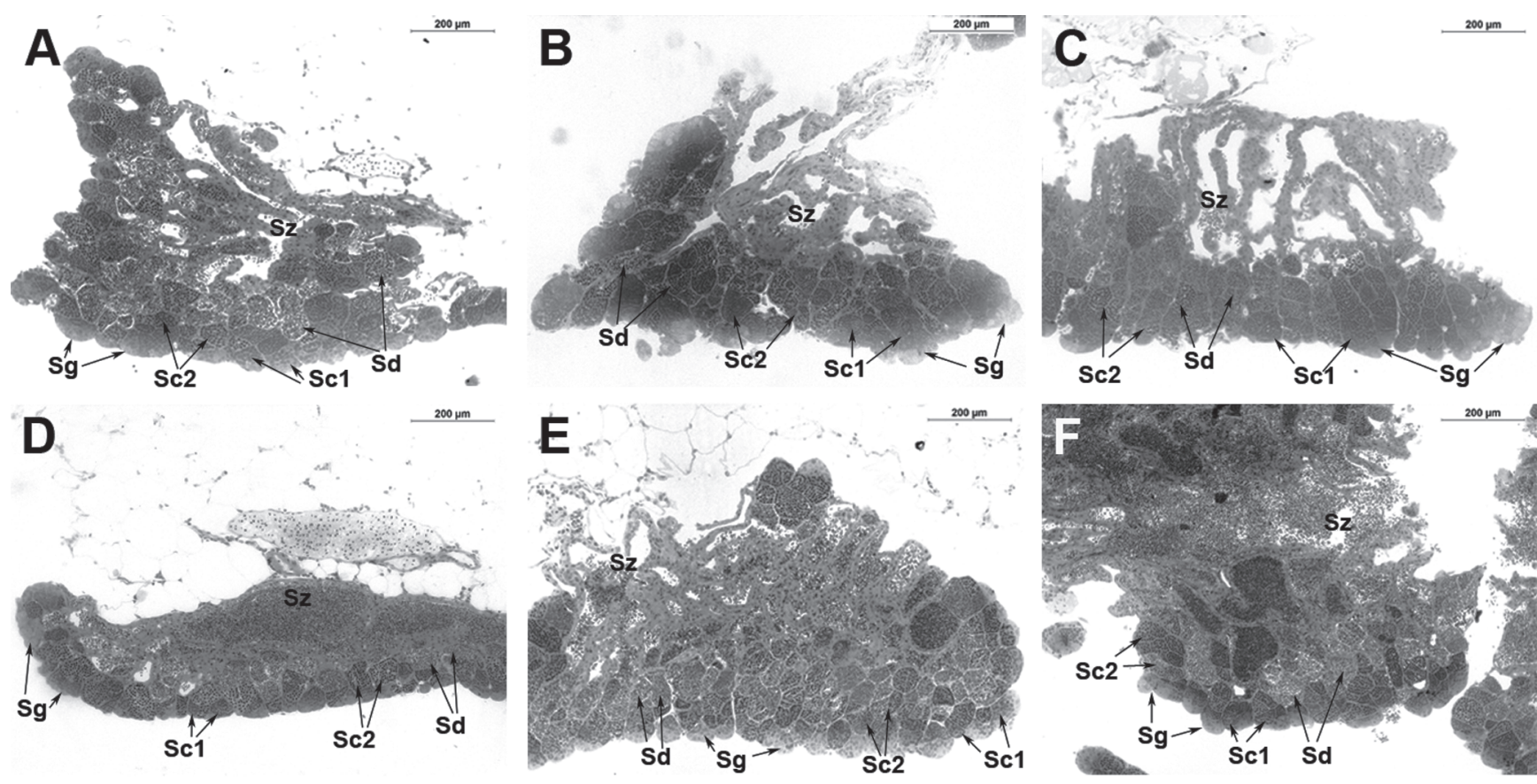

G
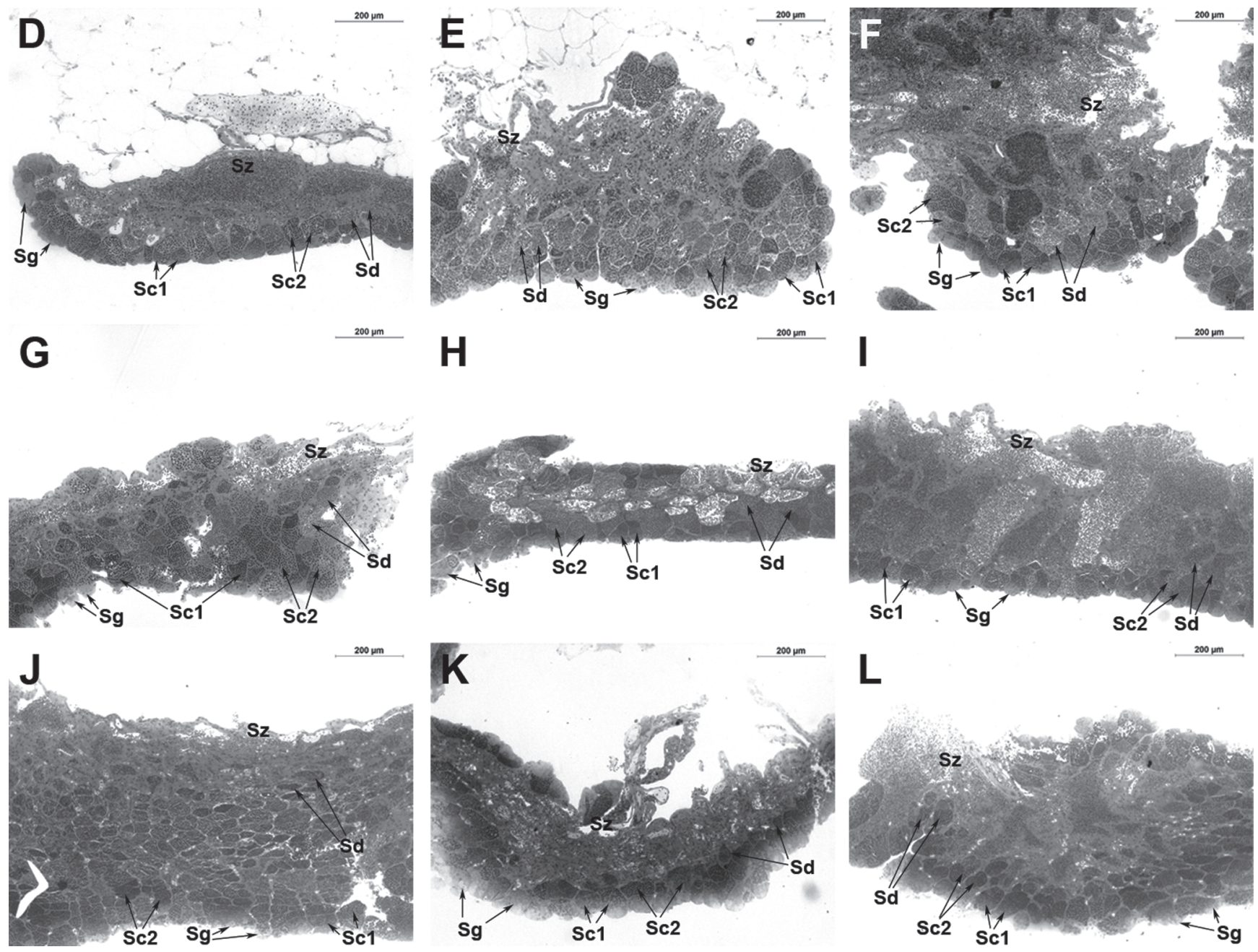

Fig. 2. Annual reproductive cycle of male from April/2010 (A) to March/2011 (L), stained with toluidine blue-borax, in which gonads presented themselves as able to reproduce in all months of the year. Observe the continuity and discontinuity of cysts. Spermatogonia (Sg), primary spermatocytes (Sc1), secondary spermatocyte (Sc2), spermatid (Sd), spermatozoa (Sz). 
Oogenesis and the female reproductive cycle. The ovaries are of a cavity cystovarian kind with the germinal compartment in the form of lamellae that protrude from the capsule into the lumen of the organ. The cavity is continuous with the ovarian gonoducts (Fig. 3A) which join distally and culminate in the urogenital papilla. Bordering the ovigerous lamellae and enclosing the ovarian lumen the germinal epithelium presents two cell types: somatic cells and germ cells. The somatic cells of the germinal epithelium stand out and will be pre-follicular cells that accompany the oogonia (Fig. 3B).

The oogonia can gather forming nests, which are groups of cells (Fig. 3B). In these nests, some cells may commit to folliculogenesis entering meiosis and give rise to early oocytes (Fig. 3C). These oocytes come in prophase and park in diplotene still in nests, epithelial cells detach from the germinal epithelium and will associate with the oocyte, becoming the pre-follicular cells (Fig. 3C).

The pre-follicular cells penetrate the nests involving and individualizing the oocytes. Then, these cells become follicular cells and with the oocyte constitute the initial ovarian follicle that remains connected to the germinal epithelium (Fig. 3C). Connective tissue cells surrounding the follicle again have around and give rise to two cell layers the internal theca and the external theca (Fig. 3C). Thus forming the follicular complex consisted of the diplotenic oocyte surrounded by a follicular epithelium and supported by the basal membrane and two layers of theca cells.

With the ovarian follicle formed the process of folliculogenesis is complete and the oocyte starts its primary growth or pre-vitellogenic growth. This type of ovarian follicle is characterized by having multiple nucleoli and the oocytes become increasingly large (Fig. $3 \mathrm{D}-\mathrm{E})$. At this stage arise the "nüages" that are clear bodies observed in the cytoplasm due to accumulation of RNA and proteins (Fig. 3D-E). The cytoplasmatic basophilia is intense. During the growth phase the follicle has an envelope composed of a pellucid zone, a layer of follicular cells, the basal membrane and theca components (Fig. 3E). The pellucid zone is an intensely stained area, PAS-positive, consisting of small microvilli that protrude on the surface of the oocyte and follicular cells; during the development of the follicles these microvilli increase in number and length and extending through pores or channels (Fig. 3F).

Even at this stage there is an intense proliferation of membranous organelles such as Golgi apparatus and endoplasmic reticulum that are visible in light microscope, which begins around the nucleus and spreads throughout the cytoplasm, reaching the periphery of the oocyte progressively. These clusters are called "Balbiani corpuscles" or yolk-nucleus (Fig. 3D-E).

There is also an arising of the cortical alveoli which are vesicles filled with glycoproteins that the PAS stain in pink and are located initially in the periphery of the oocyte. The cortical alveoli become progressively larger forming large vesicles that border the oocyte surface and mark the final stage of primary growth (Fig. 4A-D).

The follicle begins the secondary growth or vitellogenesis with a new and drastic increase in volume due to the accumulation of yolk. The nucleus has highly irregular contours and peripherals nucleoli are installed in the grooves of the nuclear envelope, these grooves match to the "nüages" of the cytoplasm (Fig. 4E). The pellucid zone is thicker and the microvilli of the oocyte and follicular cells elongate (Fig. 4E-G). The acidic polysaccharides toluidine blue metachromatic and PAS positive neutral polysaccharides (Fig. 4F) and metachromatic granules in toluidine blue (Fig. 4G) are produced and incorporated into the alveoli. With the accumulation of yolk the oocyte increases in size and cortical alveoli are displaced to the periphery (Fig. 4H-K). Completing the maturation the nucleus migrates to the periphery too.

Post-ovulatory complexes are also found in the ovary and consisting of cells that made up the follicle and that remain after the release of the oocyte (Fig. 5A). Oocytes are also observed in the process of involution or atresia (Fig. 5B) which goes through stages of degeneration and resorption.

Thus, female individuals had gonads in (Fig. 6): Ovarian development stage with oogonia and early oocytes always facing the lumen; pre-vitellogenic and vitellogenic oocytes are abundantly seen; low occurrence of mature oocytes and post-ovulatory complexes; and some atresias in the initial phase. This stage was observed more frequently from May to September (Fig. 6B-F). In the able to reproduce or able of spawning stage the mature oocytes are abundant, many post-ovulatory complexes and some advanced atresia are seen. This stage was observed from October to March (Fig. 6G-L). In the regression stage the ovaries have many atresias at different stages of development and many post-ovulatory complexes. This stage was observed in some individuals from February to April (Fig. 6K-L and 6A).

The other stages have occurred in some individuals while others were in the ovarian development stage, which was the stage most frequently observed during the year. The regeneration stage was not observed in females. Thus it is possible to characterize the annual reproductive cycle of females as discontinuous with splitted spawning.

The gonadossomatic ratio (Fig. 7A) analyzed from female individuals collected varied throughout the year ( $\mathrm{F}$ $=24.885, \mathrm{p}<0.001)$ indicating, as already detached in the description of the reproductive cycle of females, they have a period in which reproduction is more intense corresponding to the period between October to March. The same can be observed with more detail in the quantitative analysis of germ cells (Fig. 7C) and in the analysis of variation in the number of mature oocytes in each month $(\mathrm{F}=6.746, \mathrm{p}<0.001)$. The females, although with the production of mature oocytes throughout the year, are more able to reproduce in this period (Fig. 7B). 


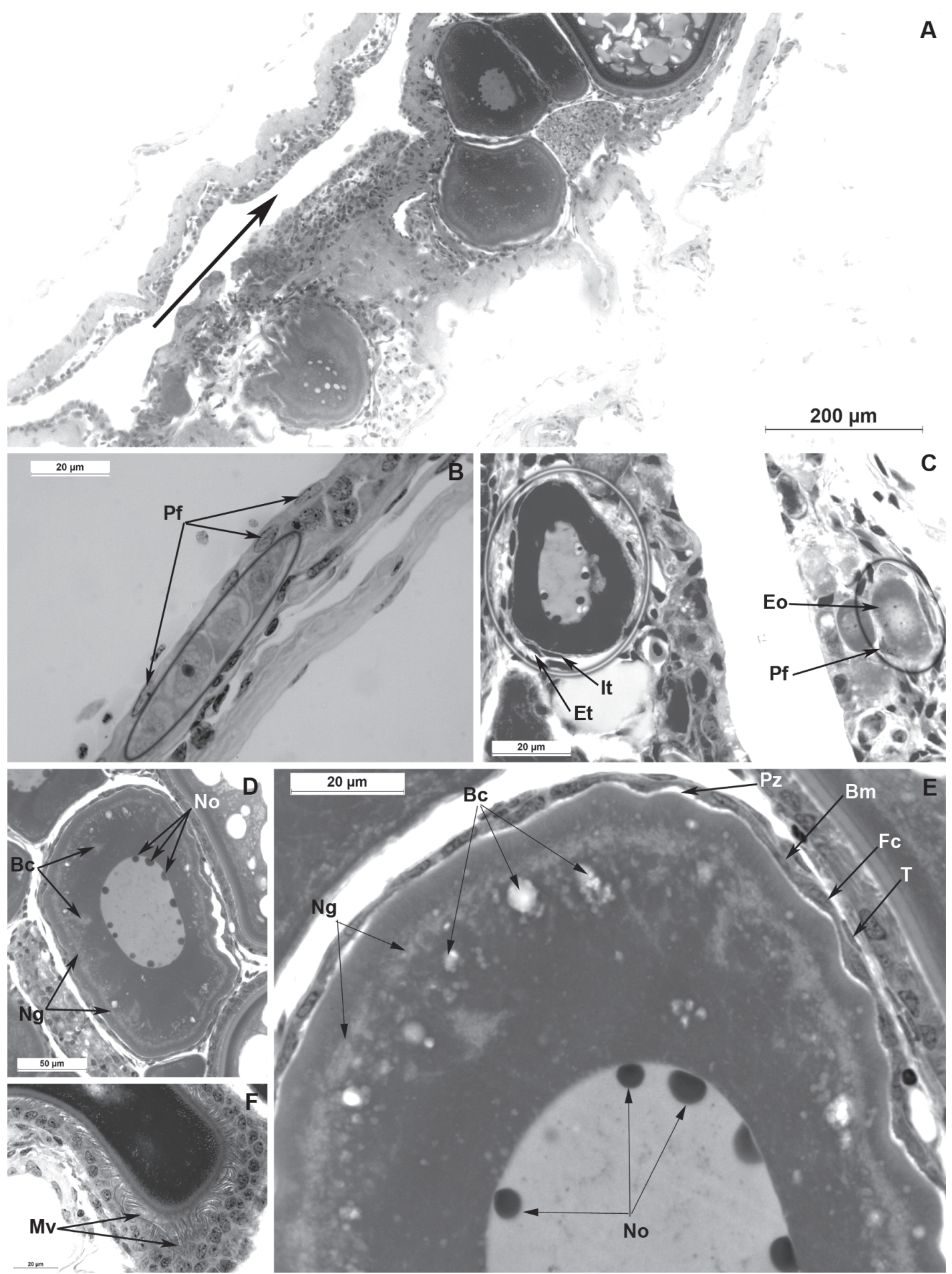

Fig. 3. In the ovaries, stained with toluidine blue-borax, (A) there is the gonoduct, as indicated by the arrow; (B) the germinal epithelium, which presents: somatic cells that stand out of the germinal epithelium and will be the pre-follicular cells (Pf) to accompany the nest of oogonia (circle); (C) some oogonia begin the process of differentiation through meiosis, forming early oocytes (Eo) that stand out from the nest being involved in pre-follicular cells (Pf) characterizing the initial ovarian follicle (black circle), after then other cells come around forming the internal theca (It) and external theca (Et), forming the follicular complex (white circle); (D) the oocyte gives rise to a new stage of growth, the pre-vitellogenic one with the arising of nüages (Ng), multiple nucleoli (No) and the Balbiani corpuscles $(\mathrm{Bc}) ;(\mathbf{E})$ it is possible to observe the anterior structures in greater detail and also the layers of the follicular envelope, which comprises the components of theca $(\mathrm{T})$, a layer of follicular cells $(\mathrm{Fc})$, the basal membrane $(\mathrm{Bm})$ and a pellucid zone $(\mathrm{Pz}) ;(\mathrm{F})$ this zone is composed by small microvilli (Mv) that protrude on the surface of the oocyte and follicular cells. 
We can also observe that there is loss of cell according to the state of cell growth (Fig. 7C). Because there is more oogonia than oocytes initial, which are more abundant than the pre-vitellogenic oocytes, and so on. However, the atretic tissue present very abundant throughout the year.

\section{Discussion}

The testes in Melanorivulus aff. punctatus are elongated pockets that converge to urogenital papilla, unlike other fish that may have testicles foliaceous performing gene,
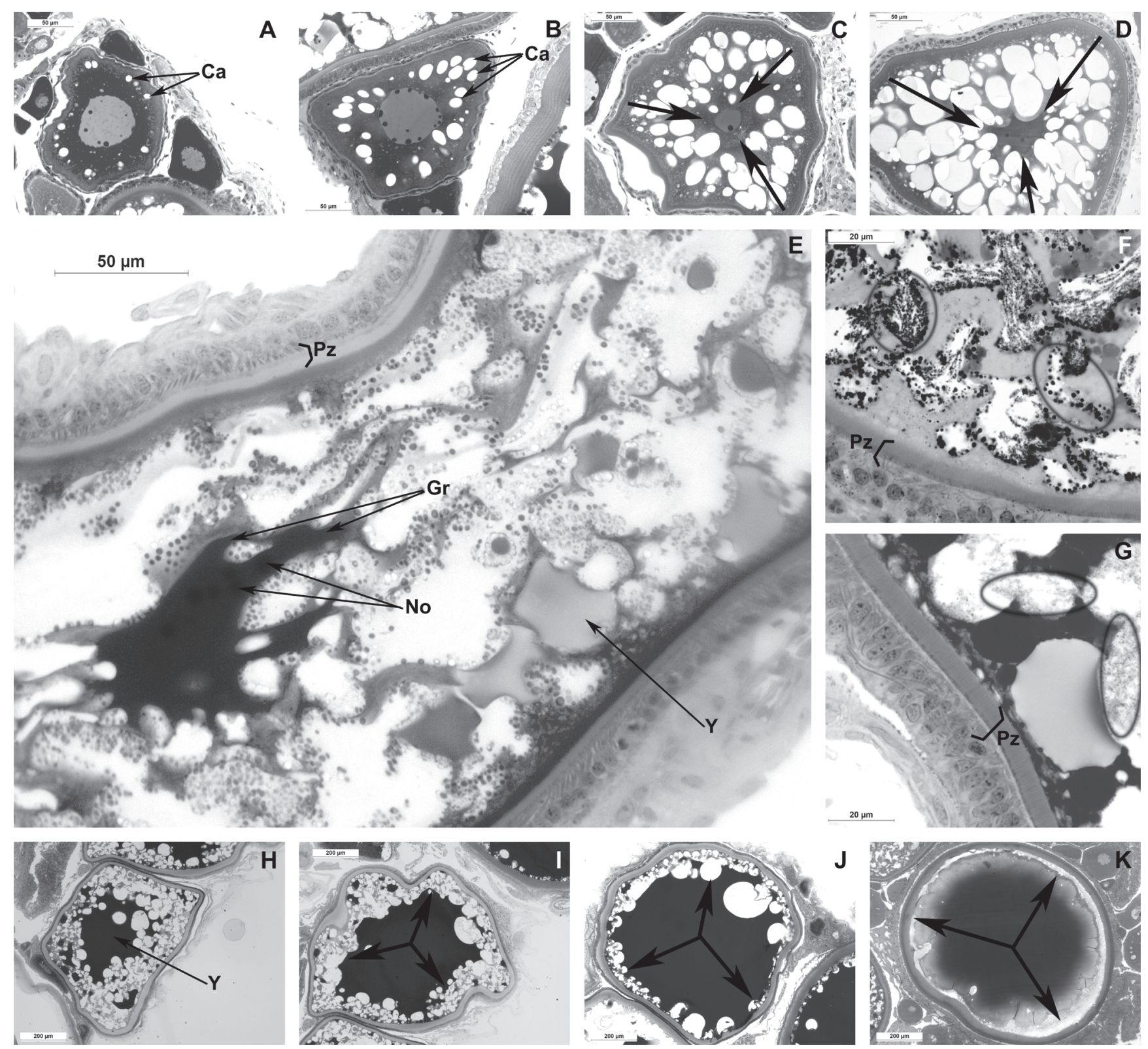

Fig. 4. The oocyte growth continues (stained with toluidine blue-borax) so (A-B) the cortical alveoli (Ca) are arranged on the periphery of the oocyte at first and (C-D) become progressively larger forming large vesicles that border the oocyte surface (as indicated by the arrows); (E) beginning the secondary growth of the ovarian follicle, there is a nucleus with grooves (Gr), the nucleoli (No) are installed in these grooves, the yolk (Y) is accumulating and the pellucid zone is becoming thicker (F and $\mathbf{G}-\mathrm{Pz}$ ); (F) acidic polysaccharides toluidine blue metachromatic and PAS positive neutral polysaccharides (circles) (stained with PAS+Hematoxilin+Metanil Yellow) and (G) metachromatic granules in toluidine blue (circle) (stained with toluidine blue-borax) are produced and incorporated into the alveoli; $(\mathbf{H}-\mathbf{K})$ so, the yolk keeps accumulating during maturation of the oocyte, as indicated by the arrows, until become a (K) mature oocyte. 
secretory and store function as described by Le Gac \& Loir (1999). A classification was proposed by Grier (1993) and Parenti \& Grier (2004) based on the shape and organization of the germinal compartment. According to this classification $M$. aff. punctatus fit in the lobular type in which germinal compartment is fingerlike and ends in a blind bottom. According to Grier (1993) this testicular type is very common among Neoteleostei, especially for Atherinomorpha and Percomorpha.

The lobular testes were identified by Grier (1993) in two subtypes in according to the distribution of spermatogonia. The lobular unrestricted, wherein spermatogonia are distributed along the lobes, is very common in Percomorpha. The lobular restricted are those wherein the spermatogonia are confined to the distal portion of lobes forming cysts

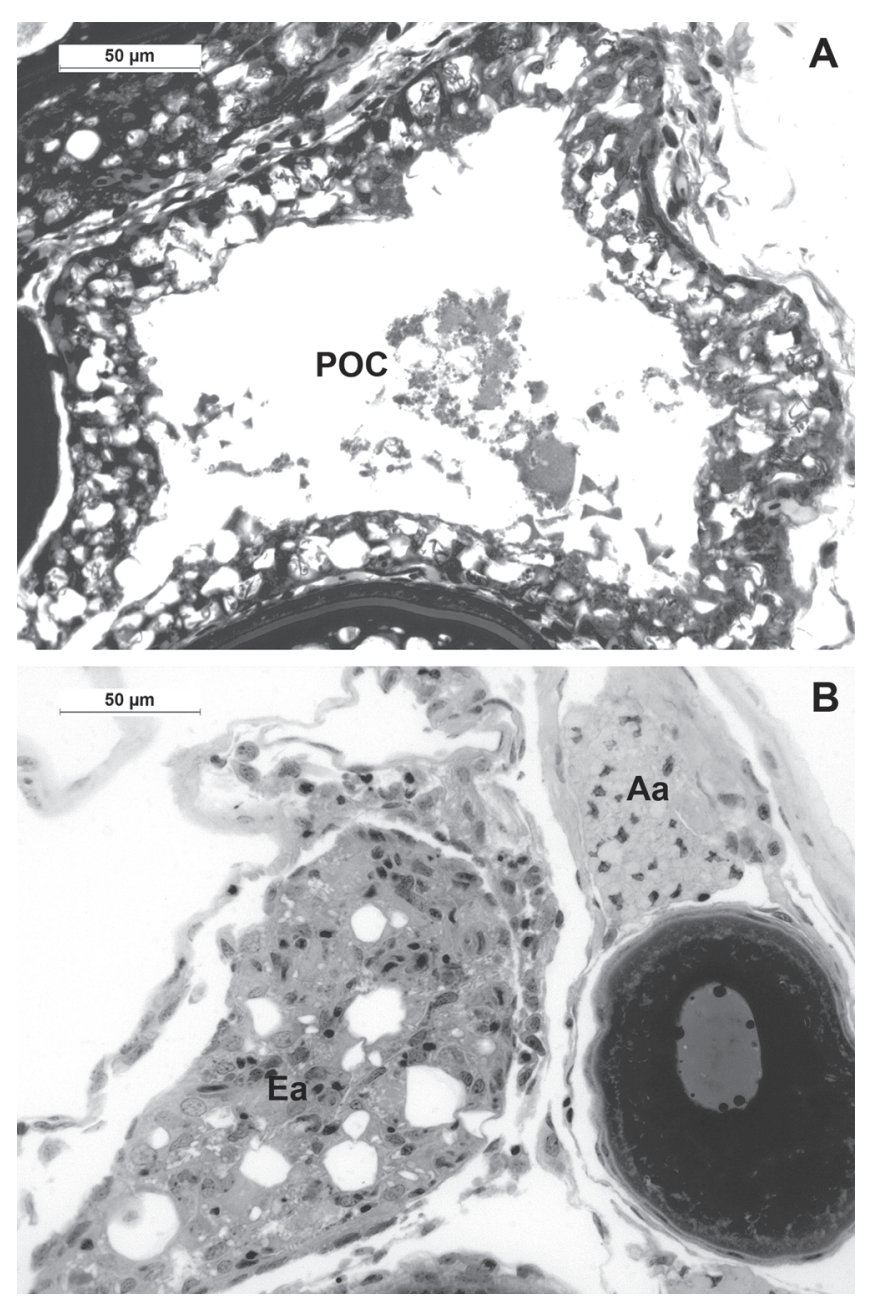

Fig. 5. After spawning, there is observed, stained with toluidine blue-borax, (A) post-ovulatory complexes (POC) consisting of cells that made up the follicle and that remain after the release of the oocyte, and (B) early (Ea) and advanced (Aa) atretic processes, which go through stages of degeneration and resorption. that, during the genesis, moves over the lobes and in the end open and the sperm are released into the duct. In Melanorivulus aff. punctatus spermatids were observed in well-defined cysts, which also have a thicker wall, featuring the cystic genesis, as described by Burns et al. (2009). Parenti \& Grier (2004) presented a table with a survey of the types of testes in Osteichthyes, and the lobular restricted is very common in Atherinomorpha, which was described by Grier (1981) in Fundulus grandis (Fundulidae) a cyprinodontiform as $M$. aff. punctatus.

The reproductive cycle observed in males of Melanorivulus aff. punctatus was classified as continuous with splitted spermiation, because there was not a specific reproductive season, but spermatogenic cysts in all different stages of development (Vazzoler, 1996) and the lumen filled with sperm in all the gonads gathered. These same characteristics can be found in Austrolebias charrua (Arezo et al., 2007), a rivulid as $M$. aff. punctatus. This can indicate that for males environmental changes have little influence on reproductive development, or that it does not require an energy effort that compromises the survival of the individual during these variations.

Melanorivulus aff. punctatus presented cystovarian type classified according to the descriptions made by Hoar (1969) and later by Grier et al. (2007). This differs from the gymnovarios, which are more common in Anguiliformes (Colombo et al., 1984) and Salmoniformes (Grier et al., 2007), by the presence of ovigerous lamellae exposed directly to the coelomic cavity and this feature facilitates the germ cells storage before spawning.

Some cellular characteristics cannot be observed by light microscopy, but explain exactly what was found under this methodology. This is the case of multiple nucleoli observed during the stage of pre-vitellogenic oocyte and described by Grier et al. (2009), which occur due to the fact that the nucleolus organizers are amplified standing out of the chromosomes and becoming circular. These oocytes are also called perinucleolar oocytes by the same authors, when the nucleoli migrate to the nuclear periphery. Likewise, the sharp cytoplasmic basophily in oocytes with primary growth or pre-vitellogenic as seen in Melanorivulus aff. punctatus is a change that occurs gradually and is due to accumulation of RNA and proteins according to Selman \& Wallace (1989). Despite these organelles are not visible by light microscopy, stains coming of these organelles that characterize the developing oocytes are called "nüages".

Another structure observed in pre-vitellogenic oocytes of Melanorivulus aff. punctatus visible by light microscopy are the Balbiani corpuscles or yolk-nucleus, also described by Hubbard (1894). These corpuscles were recognized as clusters of organelles located near the nucleus that proliferate intensely and spread throughout the cytoplasm reaching the periphery of the vitellogenic oocyte. And yet, the cortical alveoli, as observed by the Grier et al. (2009), are vesicles filled with glycoproteins and when newly formed they are on the periphery of the oocyte. They are 
formed by depressions in the membrane of the oocyte and become progressively larger. The origin of these structures has been well shown by Grier et al. (2009) using electron microscopy and marks the final stage of the primary growth or pre-vitellogenic.

The determination that the pellucid zone is composed of small microvilli projecting on the surface of egg and follicle cells can be clearly observed even under light microscopy to Melanorivulus aff. punctatus, including its increasing in number and length extending through pores. Quagio-Grassitto \& Guimarães (2003) and Grier et al. (2009) showed more conclusively that such pores result from deposition of electron-dense material which is organized in layers varying in number, thickness, chemical
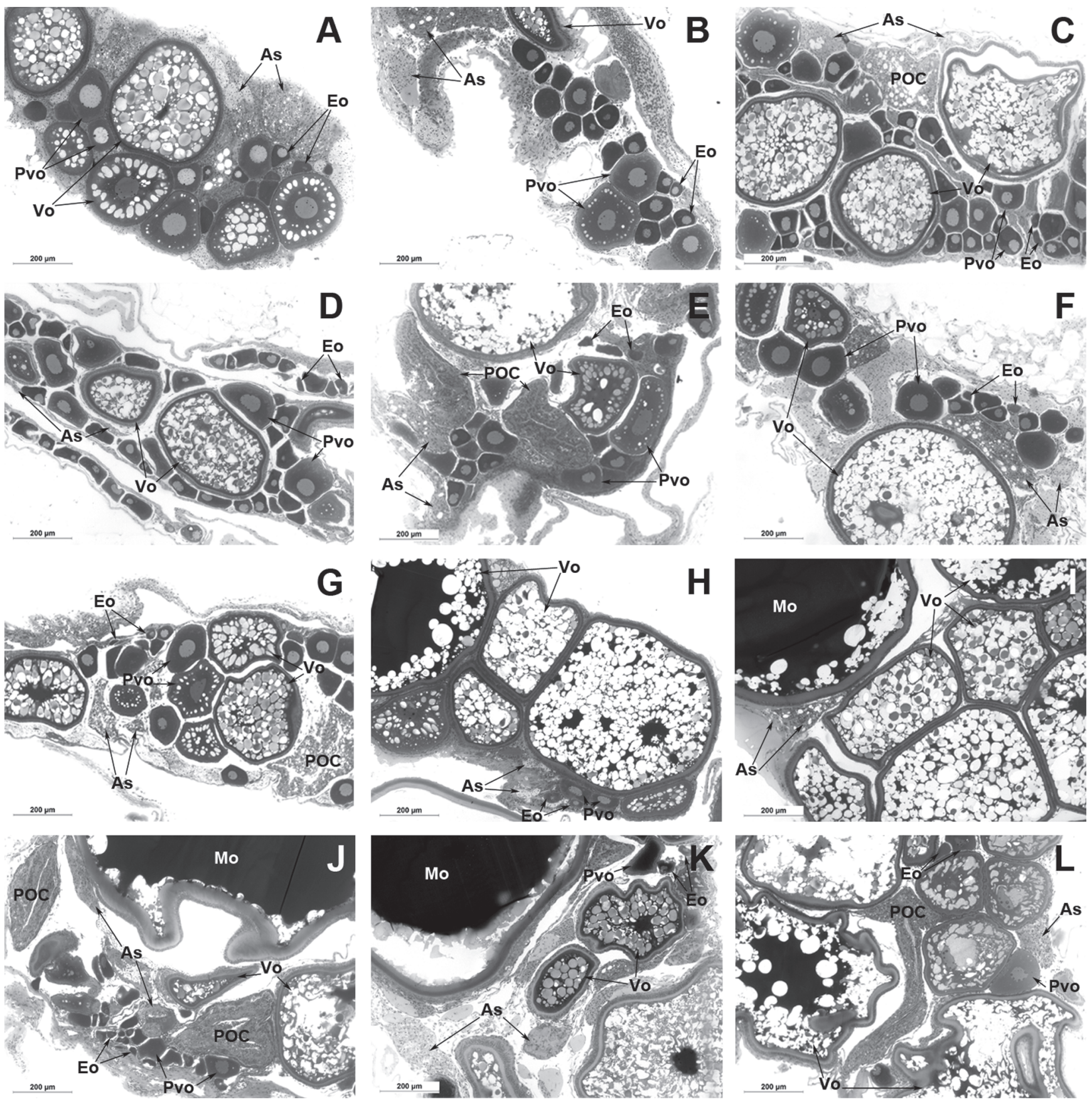

Fig. 6. Annual reproductive cycle of female April/2010 (A) to March/2011 (L), stained with toluidine blue-borax, in which ovarian development was seen more frequently from May to September, the stage of able to spawn from October to March and the stage regression from February to April. The regeneration step was not observed in females. Early oocytes (Eo), pre-vitellogenic oocytes (Pvo), vitellogenic oocytes (Vo), mature oocytes (Mo), post-ovulatory complexes (POC) and atresias (As). 

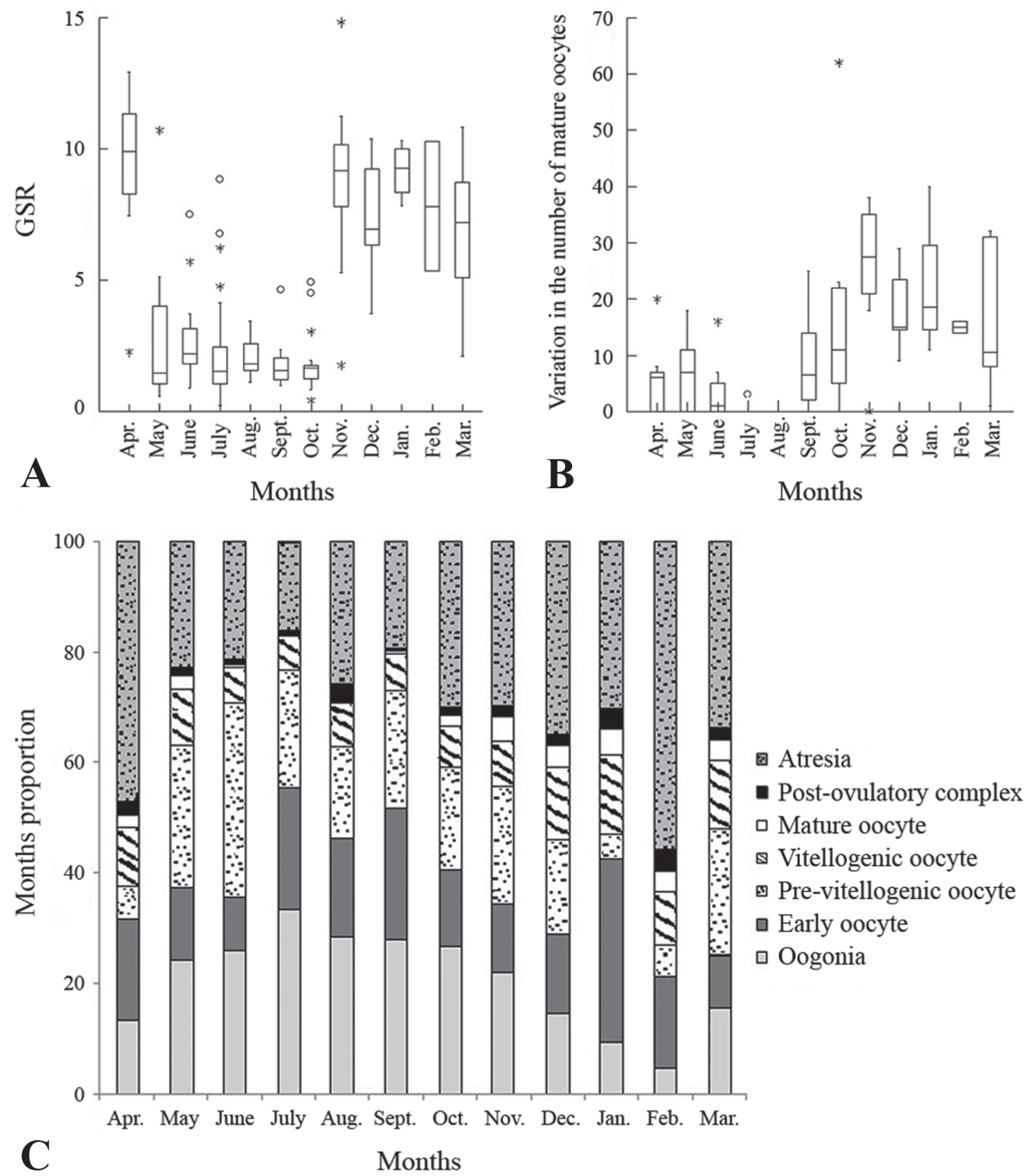

Fig. 7. Quantitative analyses of the female gonads. (A) Variation in gonadosomatic ratio (GSR) over the months $(\mathrm{F}=24.885$, $\mathrm{p}$ $<0.001)$, (B) variation in the number of mature oocytes in each month $(F=6.746, p<0.001)$ and $(\mathbf{C})$ plot of germ cells proportion monthly, indicating that they are more able to reproduce from October to March.

composition, structure and electron density in a specific manner.

The reproductive cycle observed in females of Melanorivulus aff. punctatus was classified as discontinuous with splitted spawning, due to the fact that there is a greater reproductive intensity in a given period, however there are oocytes in all different stages of development (Murua \& Saborido-Rey, 2003). For the rivulid
Austrolebias charrua (Arezo et al., 2007) it was observed a continuous reproductive cycle with splitted spawning. Whereas A. charrua is classified as annual species and observing only the rainy season, both species have similar reproductive characteristics even with the type of spawning which is considered a characteristic of species inhabiting unstable environments (Shibatta, 2005, Gonçalves et al., 2011). However, with the change in water level in the reservoir 
studied, the reproduction of $M$. aff. punctatus decreases in intensity, while for $A$. charrua the reproduction is interrupted for a period of drought.

The use of the calculations of gonadosomatic ratio (GSR) was effective for the present study therefore confirmed the results presented in the description of the reproductive cycle, by histological techniques and quantitative assessment of cellular composition of the gonads, according to the count of the germ cells. Shibatta (2005) also used the GSR calculations, but the sampling period showed long intervals because Simpsonichthys boitonei (Rivulidae) is rare and endemic, making it difficult to compare the two species.

It was observed that Melanorivulus aff. punctatus showed production of mature oocytes throughout the year, but more intensely during the rainy season (October to April). According to Nimer (1989), the Cerrado regions show two well defined seasons: from October to April, rainy and hot season, concentrated from November to March, and May to September, cold and dry season, with the driest months from June to August. This observation may indicate that the increased level of water in the rainy season can be a "trigger" for a more intense reproductive process.

Further, regarding the cellular composition of the gonads, there is cell loss according to the progress of cell development, so that there is a marked decrease in the number of cells in more advanced development compared to the basal ones. However, the atresias are abundantly presented throughout the year, which can indicate that some basal cells are being reabsorbed by the system. After all, the follicular atresia is an involutive process that occurs in ovaries of fish and other vertebrates, and is observed in all stages of the reproductive cycle, although more frequent during the post-spawning stage (Guraya, 1994). This process is more frequent in vitellogenic oocytes, but can be also found in pre-vitellogenic oocytes as noted in the study of oogenesis fish of Guraya (1986) and in Prochilodus affinis (= Prochilodus costatus) (Characiformes) of Rizzo \& Bazzoli (1995).

\section{Acknowledgments}

We thank Irani Quagio-Grassiotto (UNESP-Botucatu) for the space provided for the histological preparations and all suggestion for this work. We would also like to thank CAPES (Coordenação de Aperfeiçoamento de Pessoal de Nível Superior) for the financial support (CAPES proc. 23108.009130/10-2).

\section{Literature Cited}

Arenzon, A., A. C. Peret \& M. B. C. Bohrer. 1999. Reproduction of the annual fish Cynopoecilus melanotaenia (Regan, 1912) in a temporary water body in Rio Grande do Sul, Brazil (Cyprinodontiformes, Rivulidae). Hydrobiologia, 411: 65-70.

Arezo, M. J., S. D’Alessandro, N. Papa, R. Sá \& N. Berois. 2007. Sex differentiation pattern in the annual fish Austrolebias charrua (Cypridonodontiformes: Rivulidae). Tissue and Cell, 39: 89-98.
Brown-Peterson, N. J., D. M. Wyanski, F. Saborido-Rey, B. J. Macewicz \& S. K. Lowerre-Barbieri. 2011. A Standardized Terminology for Describing Reproductive Development in Fishes. Marine and Coastal Fisheries, 3: 52-70.

Burns, J. R., I. Quagio-Grassiotto \& B. G. M. Jamieson. 2009. Ultrastructure of spermatozoa: Ostariophysi. Vol. 8A: 287387. In: Jamieson, B. G. M. (Ed.). Reproductive Biology and Phylogeny of Fishes (Agnathans and Neotelestomi). New Hampshire: Science Publishers, Enfield.

Colombo, G., G. Grandi \& R. Rossi. 1984. Gonad differentiation and body growth in Anguilla anguilla L. Journal of Fish Biology, 24: $215-228$.

Costa, W. J. E. M. 1989. Descrição de cinco novas espécies de Rivulus das bacias dos rios Paraná e São Francisco (Cyprinodontiformes, Rivulidae). Revista Brasileira de Zoologia, Curitiba, 6: 523-534.

Costa, W. J. E. M. 1990. Análise fillogenética da família Rivulidae (Cyprinodontiformes, Aplocheiloidei). Revista Brasileira de Biologia, 50: 65-82.

Costa, W. J. E. M. 2003. Family Rivulidae (South American Annual Fishes). Pp. 526-548. In: Reis, R. E., S. O. Kullander \& C. J. Ferraris (Eds.). Check list of the freshwater fishes of South and Central America. Porto Alegre: Edipucrs.

Costa, W. J. E. M. 2004a. A new killifish genus and species from the coastal plains of north-eastern (Teleostei: Cyprinodontiformes: Rivulidae). Zootaxa, 642: 1-10.

Costa, W. J. E. M. 2004b. Relationships and redescription of Fundulus brasiliensis Valenciennes (Cyprinodontiformes: Rivulidae), with description of a new genus and notes on the classification of the Aplocheiloidei. Ichthyological Exploration of Freshwaters, 15: 105-120.

Costa, W. J. E. M. 2005. Seven new species of the killifish genus Rivulus (Cyprinodontiformes: Rivulidae) from the Paraná, Paraguay and upper Araguaia river basins, central Brazil. Neotropical Ichthyology, 3: 69-82.

Costa, W. J. E. M. 2006. Relationships and taxonomy of the killifish genus Rivulus (Cyprinodontiformes: Aplocheiloidei: Rivulidae) from the Brazilian Amazonas river basin, with notes on historical ecology. Aqua Journal of Ichthyology and Aquatic Biology, 11: 133-175.

Costa, W. J. E. M. 2011. Phylogenetic position and taxonomic status of Anablepsoides, Atlantirivulus, Cynodonichthys, Laimosemion and Melanorivulus (Cyprinodontiformes: Rivulidae). Ichthyological Exploration of Freshwaters, 22: 233-249.

Coward, K. \& N. Bromage. 1999. Spawning frequency, egg size and ovarian histology in groups of Tilapia zillii maintained upon two distinct food ration sizes from first-feeding to sexual maturity. Aquatic Living Resources, 12: 11-22.

DeVlamming, V., G. Grossman \& F. Chapman. 1982. On the use of the gonosomatic index. Comparative Biochemistry and Physiology Part A: Physiology, 73: 31-39.

Francolini, M., C. Lora Lamia, C. Bonsignorio \& F. Cotelli. 2003. Oocyte development and egg envelope formation in Oreochromis niloticus, a mouth-brooding cichlid fish. Journal of submicroscopic cytology and pathology, 35: 49-60.

Gonçalves, C. S., U. P. Souza \& M. V. Volcan. 2011. The opportunistic feeding and reproduction strategies of the annual fish Cynopoecilus melanotaenia (Cyprinodontiformes: Rivulidae) inhabiting ephemeral habitats on southern Brazil. Neotropical Ichthyology, 9: 191-200.

Grier, H. J. 1981. Cellular organization of the testis and spermatogenesis in fishes. American Zoologist, 21: 345-357. 
Grier, H. J. 1993. Comparative organization of Sertoli cells including the Sertoli cell barrier. Pp. 704-730. In: Russel, L. D. \& M. D. Griswold (Eds.). The Sertoli cell. Clearwater: Cache River Press.

Grier, H. J. 2000. Ovarian germinal epithelium and folliculogenesis in the Common Snook, Centropomus undecimalis (Teleostei: Centropomidae). Journal of Morphology, 243: 265-281.

Grier, H. J. 2002. The germinal epithelium: its dual role in establishing male reproductive classes and understanding the basis for indeterminate egg production in female fishes. Pp. 537-552. In: Creswell, R. L. (Ed.). Proceedings of the fiftythird annual Gulf and Caribbean Fisheries Institute. Fort Pierce: Mississippi/ Alabama Sea Grant Consortium.

Grier, H. J. \& R. G. Taylor. 1998. Testicular maturation and regression in the common snook. Journal of Fish Biology, 53: $521-542$

Grier, H. J., M. C. Uribe-Aranzábal \& L. R. Parenti. 2007. Germinal epithelium, folliculogenesis, and postovulatory follicles in ovaries of rainbow trout, Oncorhynchus mykiss (Walbaum,1792) (Teleostei, Protacanthopterygii, Salmoniformes). Journal of Morphology, 268: 293-310.

Grier, J. H., M. C. Uribe-Aranzábal \& R. Patiño. 2009. The ovary, folliculogenesis and oogenesis in teleosts. Pp. 25-84. In: Jamieson, B. J. M. (Ed.). Reproductive Biology and Phylogeny of Fishes (Agnathans and Neotelestomi). New Hampshire: Science Publishers, Enfield.

Guraya, S. S. 1986. The Cell and Molecular Biology of Fish Oogenesis. Monographs in developmental biology, 18: 1-223.

Guraya, S. S. 1994. Gonadal development and production of gametes in fish. Proceedings of the Indian National Science Academy, 60: $15-32$.

Hoar, W. S. 1969. Reproduction. Pp. 1-72. In: Hoar, W. S. \& D. J. Randall. (Eds.). Fish physiology - vol. 3. New York: Academic Press.

Hubbard, J. W. 1894. The yolk nucleus in Cynematogaster aggregatus Gibbons. Proceedings of the American Philosophical Society, 33: 74-83.

Jons, G. D. \& L. E. Miranda. 1997. Ovarian weight as an index of fecundity, maturity, and spawning periodicity. Journal of Fish Biology, 50: 150-156.

Le Gac, F. \& M. Loir. 1999. Male Reproductive System, Fish. Pp. 20-30. In: Knobil, E. \& J. D. Neill (Eds). Encyclopedia of Reproduction - vol. 3. San Diego: Academic Press.

Le Menn, F., J. Cerdà \& P. J. Babin. 2007. Ultrastructural aspects of the ontogeny and differentiation of ray-finned fish ovarian follicles. Pp. 1-37. In: Babin, P. J., J. Cerdà \& E. Lubzens (Eds.). The Fish Oocyte: From Basic Studies to Biotechnological Applications. Dordrecht: Springer.

Lo Nostro, F., H. Grier, L. Andreone \& G. A. Guerrero. 2003. Involvement of the gonadal germinal epithelium during sex reversal and seasonal testicular cycling in the prtogynous swamp eel, Synbranchus marmoratus Bloch, 1795 (Teleostei, Synbranchidae). Journal of Morphology, 257: 107-126.

Lowerre-Barbieri, S. K., N. J. Brown-Peterson, H. Murua, J. Tomkiewicz, D. M. Wyanski \& F. Saborido-Rey. 2011. Emerging issues and methodological advances in fisheries reproductive biology. Marine and Coastal Fisheries, 3: 32-51.

Maitelli, G. T. 2005. Hidrografia: a hidrografia no contexto regional. Pp. 272-287. In: Moreno, G. \& T. C. S. Higa (Eds.). Geografia de Mato Grosso: território, sociedade, ambiente. Cuiabá: Editora Entrelinhas.
Marshall, C. T., N. Yaragina, Y. Lambert \& O. Kjesbu. 1999. Total lipid energy as a proxy for total egg production by fish stocks. Nature, 402: 288-290.

Miranda, A. C. L., N. Bazzoli, E. Rizzo \& Y. Sato. 1999. Ovarian follicular atresia in two teleost species: a histological and ultrastructural study. Tissue \& Cell, 31: 480-488.

Munro, A. D. 1990a. General introduction. Pp. 1-11. In: Munro, A. D., A. P. Scott \& T. J. Lam (Eds.). Reproductive seasonality in teleosts: environmental influences. Florida: CRC Press.

Munro, A. D. 1990b. Tropical freshwater fish. Pp. 145-239. In: Munro, A. D., A. P. Scott \& T. J. Lam (Eds.). Reproductive seasonality in teleosts: environmental influences. Florida: CRC Press.

Murphy, W. J. \& G. E. Collier. 1997. A molecular phylogeny for Aplocheiloid fishes (Atherinomorpha, Cyprinodontiformes): the role of vicariance and the origins of annualism. Molecular Biology and Evolution, 14: 790-799.

Murua, H. \& F. Saborido-Rey. 2003. Female reproductive strategies of marine fish species of the North Atlantic. Journal of Northwest Atlantic Fishery Science, 33: 23-31.

Nimer, E. 1989. Climatologia do Brasil. IBGE, Departamento de Recursos Naturais e Estudos Ambientais, Rio de Janeiro.

Parenti, L. 1981. A phylogenetic and biogeographic analysis of Cyprinodontiform fishes (Teleostei, Atherinomorpha). Bulletin of the American Museum of Natural History, 168: 335-557.

Parenti, L. R. \& H. J. Grier. 2004. Evolution and phylogeny of gonad morphology in bony fishes. Integrative \& Comparative Biology, 44: 333-348.

Quagio-Grassiotto, I. \& A. C. D. Guimarães. 2003. Follicular epithelium, theca and egg envelope formation in Serrasalmus spilopleura (Teleostei, Characiformes, Characidae). Acta Zoologica, 84: 121-129.

Quagio-Grassiotto, I., H. Grier, T. S. Mazzoni, R. H. Nóbrega \& J. P. A. Amorim. 2011. Activity of the ovarian germinal epithelium in the freshwater catfish, Pimelodus maculatus (Teleostei: Ostariophysi: Siluriformes): Germline cysts, follicle formation and oocyte development. Journal of Morphology, 272: 1290-1306.

Quintero-Hunter, I., H. Grier \& M. Muscato. 1991. Enhancement of histological detail using metanil yellow as a counterstain in periodic acid/Schiff's hematoxylin stalning of glycol methacrylate tissue sections. Biotechnic Histochemistry, 66: 169-172.

Rizzo, E. \& N. Bazzoli. 1995. Follicular atresia in curimatá-pioa Prochilodus affinis Reinhardt, 1874 (Pisces, Characiformes). Revista Brasileira de Biologia, 55: 697-703.

Schwenk, L. M. 2005. Domínios Biogeográficos: interações entre fitogeografia e zoogeografia. Pp. 250-271. In: Moreno, G. \& T. C. S. Higa (Eds.). Geografia de Mato Grosso: território, sociedade, ambiente. Cuiabá: Editora Entrelinhas.

Schindler, I. \& V. Etzel. 2008. Re-description and distribution of Rivulus punctatus Boulenger, 1895 (Teleostei: Rivulidae) and its habitats in Paraguay. Vertebrate Zoology, 58: 33-43.

Selman, K. \& R. A. Wallace. 1989. Cellular aspects of oocyte growth in teleosts. Zoological Science, 6: 211-231.

Shibatta, O. A. 2005. Reprodução do pirá-brasília, Simpsonichthys boitonei Carvalho (Cyprinodontiformes, Rivulidae), e caracterização de seu habitat na Reserva Ecológica do Instituto Brasileiro de Geografia e Estatística, Brasília, Distrito Federal, Brasil. Revista Brasileira de Zoologia, 22: 1146-1151.

Somarakis, S., E. K. Ganias, E. G. Tserpes \& C. Koutsikopoulos. 2004. Ovarian allometry and the use of the gonosomatic index: 
a case study in the Mediterranean sardine, Sardina pilchardus. Marine Biology, 146: 181-189.

Suzuki, H. I., A. E. A. M. Vazzoler, E. E. Marques, M. A. P. Lizama \& P. Inada. 2004. Reproductive ecology of the fish assemblages. Pp. 271-291. In: Thomaz, S. M., A. A. Agostinho \& N. S. Hahn (Eds.). The upper Paraná River and its floodplain: physical aspects, ecology and conservation. Leiden: Backhuys Publishers.

Vazzoler, A. E. A. M. 1996. Biologia da reprodução de peixes teleósteos: teoria e prática. Eduem, SBI.

West, G. 1990. Methods of assessing ovarian development in fishes: a review. Australian Journal of Marine and Freshwater Research, 41: 199-222.

Wootton, R. J. 1990. Ecology of teleost fishes. London: Chapman \& Hall.

Submitted May 3, 2012

Accepted November 26, 2012 by Clarice Bernhardt Fialho

Published March 31, 2013 